\title{
Community Structure Of Coral Reefs In Saebus Island, Sumenep District, East Java
}

\author{
Mada Rizmaadi ${ }^{1,2, *}$, Johannes Riter ${ }^{1,2}$, Siti Fatimah $^{1,2}$, Riyan Rifaldi ${ }^{1,3}$, Arditho Yoga ${ }^{1,2}$, Fikri Ramadhan ${ }^{1,2}$, and \\ Ambariyanto Ambariyanto ${ }^{2,4}$ \\ ${ }^{1}$ UKSA-387 Diving Club Diponegoro University, 50275 Jl. Prof. Soedarto SH, Tembalang Campus, Semarang, Indonesia \\ ${ }^{2}$ Faculty of Fisheries and Marine Science, Diponegoro University, $50275 \mathrm{Jl}$. Prof. Soedarto SH, Tembalang Campus, Semarang, \\ Indonesia \\ ${ }^{3}$ Faculty of Engineering, Diponegoro University, 50275 Jl. Prof. Soedarto SH, Tembalang Campus, Semarang, Indonesia \\ ${ }^{4}$ Coastal Disaster Rehabilitation and Mitigation Center, Integrated Laboratory, Diponegoro University, 50275 Jl. Prof. H. Soedarto, SH, \\ Tembalang, Semarang, Indonesia
}

\begin{abstract}
Increasing degradation coral reefs ecosystem has created many concerns. Reduction of this damage can only be done with good and proper management of coral reef ecosystem based on existing condition. The condition of coral reef ecosystem can be determined by assessing its community structure. This study investigates community structure of coral reef ecosystems around Saebus Island, Sumenep District, East Java, by using satellite imagery analysis and field observations. Satellite imagery analysis by Lyzenga methods was used to determine the observation stations and substrate distribution. Field observations were done by using Line Intercept Transect method at 4 stations, at the depth of 3 and 10 meters. The results showed that the percentage of coral reef coverage at the depth of 3 and 10 meters were $64.36 \%$ and $59.29 \%$, respectively, and included in fine coverage category. This study found in total 25 genera from 13 families of corals at all stations. The most common species found were Acropora, Porites, and Pocillopora, while the least common species were Favites and Montastrea. Average value of Diversity, Uniformity and Dominancy ind ices were 2.94, 0.8 and 0.18 which include as medium, high, and low category, respectively. These results suggest that coral reef ecosystems around Saebus Island is in a good condition.
\end{abstract}

\section{Introduction}

Saebus Island is one of the islands that located in Kangean Islands, East Java, Indonesia. Administratively, this island is located at Sapeken Subdistrict, Sumenep District of East Java Province. Coastal areas of this archipelago have high potential of natural resources, one of the largest marine resources is coral reef ecosystem [1]. According to [2], Sumenep District waters has areas of coral reefs covering 47,760.9 Ha, is the largest coral reefs area in East Java Province.

Coral reefs are known as tropical marine ecosystems with high productivity, which has important role not only on biodiversity including genetic but also on fisheries productivity $[3,4]$. As one of habitat, food source, spawning and growth spots for fish communities [5], coral reefs become very important in Kangean Archipelago region where the majority of coastal communities have livelihoods in the fisheries sector [6].
However, on the past few years, coral reef ecosystems on the region experienced drastic degradation due to destructive fishing activities using explosives and potassium [6]. Destructive fishing has been reported in Indonesia marine areas [7,8], and has caused reducing biodiversity and increasing extinction of marine organisms [9,10]. Generally, almost $45 \%$ of coral reefs in Indonesia are under high threat due to human exploitation activities as well as threat of temperature change and coral bleaching [11].

In order to reduce the rate of coral reef degradation, better management has to be implemented based on existing condition both threats and coral ecosystem. Therefore, ecological research on coral reef ecosystem is needed to base line condition of coral reef in the region [12]. This research aims to determine the structure of coral reef community in Saebus Island waters that includes measurement of cover percentage, diversity, uniformity, and dominance of coral reef communities.

\footnotetext{
*Corresponding author: madarizmaadi95@gmail.com
} 


\section{Methods}

The research is conducted on September to November 2016 at Saebus Island, Sapeken Sub-district, Sumenep District, East Java. The research stations determined by purposive sampling method, based on Satellite imaging by Lyzenga methods. The observations were conducted at 4 stations, based on fairly good living coral coverage area from satellite imaging, also represent 4 different cardinal points. See Figure 1.
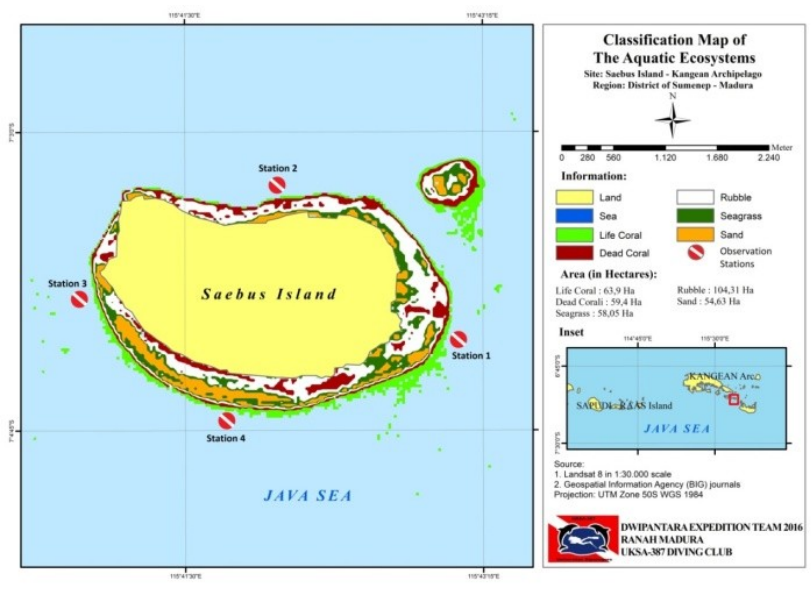

Figure 1. Map of research location

\subsection{Field observation}

Coral reef condition analyzed using Line Intercept Transect (LIT) observation [13] at 4 different stations at the depth of 3 and $10 \mathrm{~m}$. coral reef data were recorded by measuring the diameter and record coral genus found along the transect.

\subsection{Coral percent cover}

Percentage of coral reefs community cover was obtained using [14] formula. Coral reefs conditions were categorized based on coral cover percentage with reference to Environmental Ministry Decree No.4/2001 (Table 1) [15] about fixed criteria of coral reefs damage.
Table 1. Category of coral reefs condition based on percent of live coral cover [15]

\begin{tabular}{|l|l|l|}
\hline \multicolumn{2}{|c|}{ Category } & Percentage \\
\hline \multirow{2}{*}{ Bad } & Poor & $0-24.9$ \\
\cline { 2 - 3 } & Fair & $25-49.9$ \\
\hline \multirow{2}{*}{ Good } & Good & $50-74.9$ \\
\cline { 2 - 3 } & Excellent & $75-100$ \\
\hline
\end{tabular}

\subsection{Diversity, uniformly and dominancy index}

Diversity index is measurement of community abundance, observed from the number of species/genus in one area, calculated with Shannon-Wiener Formula on [16].

Uniformity index represents the number of individual among species in one community, calculated with formula of [17]. The more balanced distribution of individual among species, the balance of the ecosystem will be increased.

Low Uniformity and diversity index represents dominancy of one species towards other species, and vice versa. Dominancy index calculated with Equation of [18].

\section{Results}

\subsection{Coral reef conditions}

From satellite imaging by Lyzenga algorithm displayed that Saebus Island has 227.61 Ha of coral reef area, with coverage of 63.9 ha of living coral, 59.4 ha of dead coral and 104.31 of abiotic substrate (Figure 1). Coral reefs on Saebus Island are categorized as Fringing reef type. Almost all of stations have similar characteristic. On the depth of 1 to $3 \mathrm{~m}$ form coastline to slope forms flat coral reef overlay, while on the depth of more than $3 \mathrm{~m}$ is reef slope. But, $4^{\text {th }}$ station have quite different characteristic, on the depth of 1-10 $\mathrm{m}$ have low sloping degree and tends to form reef flat overlay from coast line to open ocean.

Table 2. Percent coral cover(\%), coral reef condition, and number of genus in Saebus Island

\begin{tabular}{|c|c|c|l|c|}
\hline Stations & Depth $(\mathbf{m})$ & Coral cover $(\%)$ & Conditions & Number of genus \\
\hline St.1 & 3 & 57.46 & Good & 8 \\
\hline & 10 & 77.46 & Excellent & 10 \\
\hline St.2 & 3 & 62.62 & Good & 14 \\
\hline & 10 & 61.85 & Good & 12 \\
\hline St.3 & 3 & 74.58 & Good & 10 \\
\hline & 10 & 44.83 & Fair & 14 \\
\hline St.4 & 3 & 62.89 & Good & 15 \\
\hline & 10 & 52.48 & Good & 14 \\
\hline
\end{tabular}

Based on coral reef coverage percentage classification (Table 2), coral reef at Saebus Island categorized on "Fair" to "Excelent". On $1^{\text {st }}$ Station (10 $\mathrm{m}$ of depth), Coral reef condition categorized 
on "Excellent" condition with coverage percentage is $77.46 \%$. While on the $3^{\text {rd }}$ station ( $10 \mathrm{~m}$ of depth), coral reef condition categorized on "Fair" condition with $44.83 \%$ of area covered by coral. While the rest categorized on good condition with $52.48 \%$ $74.56 \%$ area covered. Generally coral reef condition is good, there's no station categorized as "Poor" condition.

\subsection{Diversity of corals}

Based on genera diversity, station $4(3 \mathrm{~m})$ has the highest number of corals genus i.e. 15 genera were found. Then in a row $2^{\text {nd }}$ station $(3 \mathrm{~m}), 4^{\text {th }}$ station $(10 \mathrm{~m})$ and $3^{\text {rd }}$ station $(10 \mathrm{~m})$ with 14 genera found. While $1^{\text {st }}$ station $(3 \mathrm{~m})$ have least genera found with only 8 genera (Tabel 2 ).
Generally there are 25 genera of coral found on Saebus Island. Those 25 genera belongs to 13 famili, such as Acroporidae (5 genera), Astrocoeniidae (1 genus), Faviidae (5 genera), Fungiidae (1 genus), Helioporidae (1 genus), Merulinidae (1 genus), Milleporidae (1 genus), Mussidae (2 genera), Oculinidae (1 genus), Pectiniidae (1 genus), Pocilloporidae (3 genera), Poritidae (2 genera), and Siderastreidae (1 genus).

The most common coral found belongs to Acropora with high percentage at every station, ranging from $20.75 \%$ to $42.43 \%$. Followed by Porites and Pocillopora with coverage percentage of $0.63 \%-10.75 \%$ found on every observation station. While the least found coral is Favites and Montastrea with less than $1 \%$ of coverage, and found only in 1 station. All of the data presented on Table 3.

Table 3. Kind of genus list and hard coral coverage (\%) in Saebus Island

\begin{tabular}{|c|c|c|c|c|c|c|c|c|c|}
\hline \multirow{2}{*}{ Family } & \multirow{2}{*}{ Genus } & \multicolumn{2}{|c|}{ Station 1} & \multicolumn{2}{|c|}{ Station 2} & \multicolumn{2}{|c|}{ Station 3} & \multicolumn{2}{|c|}{ Station 4} \\
\hline & & 3 & 10 & 3 & 10 & 3 & 10 & 3 & 10 \\
\hline \multirow[t]{5}{*}{ Acroporidae } & Acropora & 29.40 & 42.43 & 27.59 & 26.13 & 39.11 & 20.75 & 28.90 & 23.53 \\
\hline & Anacropora & - & 0.95 & 3.88 & 12.63 & - & 0.25 & - & - \\
\hline & Astreopora & - & - & - & - & - & 0.69 & 0.25 & 0.25 \\
\hline & Montipora & 8.40 & - & - & - & - & - & 2.00 & 1.19 \\
\hline & Palac lavarina & - & 7.89 & 4.40 & - & - & - & - & - \\
\hline Astrocoeniidae & Palauastrea & - & 3.47 & - & - & - & - & - & - \\
\hline \multirow[t]{5}{*}{ Faviidae } & Cypastrea & - & - & 4.13 & 1.25 & - & - & 1.13 & 0.88 \\
\hline & Favia & 6.60 & 1.58 & - & 1.00 & 6.73 & - & - & - \\
\hline & Favites & - & - & - & 0.63 & - & - & - & - \\
\hline & Goniastrea & - & - & 0.63 & 2.94 & 9.09 & 0.20 & 0.50 & 0.50 \\
\hline & Montastrea & - & - & 0.50 & - & - & - & - & - \\
\hline Fungiidae & Fungia & - & 0.63 & 0.13 & 3.63 & 1.50 & 0.13 & - & - \\
\hline helioporidae & Heliopora & - & - & - & 0.50 & - & 0.13 & 2.25 & 0.38 \\
\hline Merulinidae & Hydnopora & - & 12.78 & - & - & - & - & 0.50 & 0.38 \\
\hline Milleporidae & Millepora & - & - & 5.25 & 4.25 & 4.50 & 9.68 & - & - \\
\hline \multirow[t]{2}{*}{ Mussidae } & Lobophyllia & 0.10 & - & 1.88 & - & - & 0.13 & 0.75 & 0.63 \\
\hline & Symphyllia & - & - & - & - & - & 1.25 & 0.25 & - \\
\hline Oculinidae & Galaxea & - & - & 0.50 & - & - & - & 0.50 & 0.50 \\
\hline Pectiniidae & Oxypora & - & - & 1.50 & 2.13 & - & - & 0.50 & 0.50 \\
\hline \multirow[t]{3}{*}{ Pocilloporidae } & Pocillopora & 3.10 & 4.10 & 1.75 & 0.63 & 2.08 & 0.56 & 10.75 & 9.50 \\
\hline & Seriathopora & 3.10 & - & - & - & 2.25 & 0.13 & 2.75 & 1.13 \\
\hline & Stylophora & - & - & - & - & 1.13 & - & - & - \\
\hline \multirow[t]{2}{*}{ Poritidae } & Goniopora & 3.00 & 2.21 & 0.38 & - & - & 3.05 & 5.05 & 7.30 \\
\hline & Porites & 3.76 & 1.42 & 10.10 & 6.13 & 3.13 & 7.50 & 6.81 & 5.81 \\
\hline Siderastreidae & Psammocora & - & - & - & - & 5.06 & 0.38 & - & - \\
\hline
\end{tabular}

\subsection{Diversity, uniformly and dominancy of coral reefs community}

As Known in Table 4, coral reef diversity rates on Saebus Island Categorized as fair to high category with indices ranging from 2.52 to 3.24 . Refers on [16], the diversity value of $1>\mathrm{H}^{\prime}>3$ is categorized as fair diversity and fair community, while $\mathrm{H}^{\prime}>3$ is a high diversity and high community category. $1^{\text {st }}$ and $3^{\text {rd }}$ stations have fair diversity levels with indices of 2.81 , 
2.65 and 2.52. While other stations have a high level of diversity. Uniformity index at all of the station categorized as high with index ranging from 0.66 to 0.99 . Refers on [17], uniformity index ranging $0.6<\mathrm{E}<$ 1 categorized as high uniformity and stable community. While dominancy index represents low dominancy rate from all of the station, ranging from 0.14 to 0.24 . According to [18], dominancy index ranging from more than 0 to less than 0.5 categorized as low dominancy can be concluded that there's no dominant coral on the area.

Table 4. Diversity, Uniformly and Dominancy indices

\begin{tabular}{|c|c|c|c|c|c|c|}
\hline \multirow{2}{*}{ Stasiun } & \multicolumn{2}{|c|}{$\mathbf{H}^{\prime}$} & \multicolumn{2}{c|}{ E } & \multicolumn{2}{c|}{ C } \\
\cline { 2 - 7 } & $\mathbf{3 m}$ & $\mathbf{1 0 m}$ & $\mathbf{3 m}$ & $\mathbf{1 0 m}$ & $\mathbf{3 m}$ & $\mathbf{1 0 m}$ \\
\hline St.1 & 2.81 & 2.65 & 0.74 & 0.70 & 0.19 & 0.24 \\
\hline St.2 & 3.03 & 3.08 & 0.80 & 0.81 & 0.18 & 0.16 \\
\hline St.3 & 3.05 & 2.52 & 0.99 & 0.66 & 0.19 & 0.23 \\
\hline St.4 & 3.24 & 3.16 & 0.85 & 0.83 & 0.15 & 0.14 \\
\hline
\end{tabular}

\section{Discussions}

\subsection{Coral diversity and composition}

Overall, 25 corals genera were found at the survey sites which consist of 13 families. The most common genera found are Acropora, Porites and Pocillopora. While the least genera found are Favites dan Montastrea genera. [4] Reported that, Saebus Island has a coral reef that is still beautiful with the potential of coral reefs on the type of Acropora and Porites. The statement is similar to the results of this research which shows that the genus Acropora is the dominant coral species in each observation station with percent cover reach $20.75 \%$ $42.43 \%$, followed by Porites with percentage of $1.42 \%$ - $10.10 \%$, then genus Pocillopora with percentage $0.63 \%$ - $10.75 \%$. Dominancy of Acropora was also reported in other islands such as Gangga island [19].

Generally, Acropora branching corals are more likely to dominate at a location with supporting water conditions because they have higher growth rates than other species [12]. Acropora branching is able to grow very rapidly with a growth rate of 5-20 cm per year, inversely proportional to the Porites massive lifeform whose radial growth rate is only $1-2 \mathrm{~cm}$ per year [12]. The existence of resistant species against environmental stresses such as massive Porites lifeform is directly proportional to the level of diversity in an area, the higher its existence the higher the diversity in the area. Otherwise if a community is dominated by susceptible species such as Acropora and Pocillopora then the species diversity will be lower [3].

The results showed that the level of diversity in the research area with an average value of 2.94 index included in the category of fair diversity and fair community condition. This situation is thought to be due to variations in the presence of resistant species and susceptible coral species [3]. However, the dominance level in the area belongs to the low category with the index of $0.14-0.24$, indicating that there is not actually a genus that dominates excessively in the area. This is supported by a high level of uniformity with an index of 0.66 to 0.99 . The higher uniformity index will indicate the higher uniformity of the population in the community, meaning that the spread of individuals of each species around Saebus island waters is fairly quite and the condition of the community in the location tends to be stable $[17,20]$.

\subsection{Coral reefs condition}

Sapeken Sub-district has the largest coral reef area compared to 21 other Sub-districts in Sumenep district with an area of $21,790.70 \mathrm{Ha}$ [2]. The result of satellite image analysis shows that Saebus Island has coral reef area of $227.61 \mathrm{Ha}$ which approximately $0.01 \%$ of coral reefs area in Sapeken Sub-district waters. The results of this study also show that coral reefs in Saebus Island can be categorized into "fair", "good", to "excellent" with live coral cover percentage of $44.83 \%-77.46 \%$. This condition is better if it is compared with other islands around Kangean Island, such as Mamburit Island with corals live cover between $35 \%$ - 75\% [6], and also Kangean Island with coral reefs area that classified as "poor" condition with coral live cover about $9.40 \%$ - $18.36 \%$ [21].

The condition of coral reefs on Saebus Island has potential in the fisheries and tourism sectors. Acording to [22], fisheries and coastal resources in Sapeken waters are the greatest and realistic potential for sustainable empowerment with more than 30 fish families identified in this area. But based on this study, at several observation stations were found unnatural coral reefs damage, indicated by the impact of explosives or potassium. It was characterized by a rubble area that forms a crater among other coral reefs communities in that area. Based on the observation result, the percentage of rubble substrate covered $0.25 \%-25.50 \%$. High percentage of rubble can indicate that was damaged by human activities that affect the environment [21]. Damaged coral reefs in Kangean Archipelago are impacted of illegal fishing activities and overfishing use explosives and potassiums that often occur in the region [6,4]. Many fishermen are aware of their fishing activities that can damage the environment. However, with the perspective that protection / conservation policies will reduce the chance of catching fishes, then subsequent damage to aquatic resources is no longer cared [23].

By looking at the potential of coastal resources and coral reef damage issues in this area, there needs to be a protective action against the aquatic environment especially coral reefs by the authorities, as well as rehabilitation action on the damaged water environment [24]. However, very little information can be accessed to determine the condition of coral reefs in this region. Therefore, further research is needed to support relevant parties to develop appropriate and beneficial policies for the environment and civil 
society. This research has provided general information about the condition of coral reefs community on Saebus Island, so it is expected to be a useful reference for other research that will be conducted around the area.

\section{Conclusions}

The conditions of coral reefs ecosystem at Saebus Island was categorized as "good" with average coral cover respectively 64.36 and 59.29 at depths of 3 and 10 meters. There were 25 genera of corals belongs to 13 families from all stations. The most common genera found were Acropora, Porites, and Pocillopora, while the least common genera were Favites and Montastrea. The Diversity levels of corals was included medium category with average Index of 2.94. Uniformity levels are included in high category with the average index of 0.80 , while the dominance levels are included in the low category with the average index of 0.18 .

\section{Acknowledgements}

This research was held by UKSA-387 Diving Club Diponegoro University on Dwipantara V Expedition: Kangean Archipelago "Jelajah Pesona Bahari Tampuk Timur Madura". We thanks to UKSA-387 Diving Club families who have fully supported and big appreciation to the Dwipantara V Expedition Team who has worked hard in this project. This project depends on logistical and field support from a number of contributed peoples. We thanks to the Department of Fisheries and Marine of East Java Province, Indonesia. Mr. H. Muhammad Ali, Mr. Osnan, Saur-Saebus village and Sapeken Sub-district governments, as well as the entire community of Saebus and Sapeken Islands for supports this research. We also give an apreciation to Prof. Ambariyanto, MSc, Ph.D., Diponegoro University, as our Supervisor who has directed and gave helpful suggestions.

\section{References}

1. M.A. Sutanto, R. Bedjo, and C.Y. Elishabeth, Petra Christian University. Surabaya (2013). (in Bahasa).

2. F.F. Muhsoni, M. Syarief, and Effendi, M. Jurnal Kelautan, 4,1: 96-101, (2011). (in Bahasa).

3. Munasik and R.M. Siringoringo, Ilmu Kelautan (Indonesian Journal of Marine Sciene), 16,1: 4958 (2011). (in Bahasa).

4. A.S. Ackiss, S. Pardede, E.D. Crandall, M. Ablan-Lagman, A. Carmen, P.H. Barber, and K.E. Carpenter, Marine Ecology Progress Series, 480: 185-197. DOI: 10.3354/meps10199 (2013).

5. J.W. Nybakken, Marine Biology An Ecological Approach. 457 pp (PT. Gramedia, Jakarta, 1988). (in Bahasa).
6. B. Tamam, A. Apri, and M. Saleh, Jurnal Kelautan, 6,2: 120-127. DOI: http://dx.doi.org/ 10.21107/jk.v6i2.785 (2013). (in Bahasa).

7. L. Pet-Soede, and M. Erdmann, SPC Live Reef Fish Information Bulletin, 4: 28-36 (1998).

8. P. Mous, L. Pet-Soede, M. Erdmann, H. Cesar, Y. Sadovy, and Pet, J. Collected essays on the economics of coral reefs: 69-76 (2000). Kalmar, Sweden: CORDIO, Kalmar University.

9. H. Cesar, L. Burke, and L. Pet-Soede, (Cesar Environmental Economics Consulting (CEEC), 2003).

10. Ambariyanto. IOP Conference Series: Earth and Environmental Science, 55,1: 012002 (2017). IOP Publishing.

11. C.L. Huffard, MV. Edmann, and T. Gunawan, (Ministry of Maritime Affairs and Fisheries \& Marine Protect Areas Govermence, Jakarta, 2012).

12. T. Toda, T. Okashita, T. Maekawa, B.A.A. Alfian, M.K. Rajuddin, R. Nakajima, W. Chen, K.T. Takahashi, B.H. Othman, and M. Terazaki, Journal of Oceanography, 63: 113-123 (2007).

13. S. English, C. Wilkinson, and V. Baker, Survey Manual for Tropical Marine Resources. 368 pp (Australian Institute of Marine Science, Townsville, 1994).

14. E. D. Gomez, and H. T. Yap, Monitoring Reef Condition. P:187-195 in R. A. Kenchington and B.E.T. Hudson (eds.), Coral Reef Management Hand book. (UNESCO Regional Office for Science and Technology for South East Asia, Jakarta, 1988).

15. State Minister for the Environment of Republic Indonesia. Minister of Environment Decree No. 04 in 2001. About Fixed Criteria of Coral Reef Quality Standard. Jakarta (2001). (in Bahasa).

16. J. A. Ludwig, and J.F. Reynolds, Statistical Ecology, A Primer on Methods and Computing. 337 pp (Jhon Wiley \& Sons, Inc. TorontoCanada, 1988).

17. C. J. Krebs, Ecologycal Methodology. 620 pp (Wm. C. Brown Publisher, Dubuque, 1989).

18. E. P. Odum, Fundamental of Ecology, $3 \mathrm{rd}$ Edition. 564 pp (W.B. Sounders Co., Philadelphia and London, 1971).

19. Souhoka, J. Ilmu Kelautan, 18,4: 213-224. DOI: https://doi.org/10.14710/ik.ijms. 18.4.213-224 (2013). (in Bahasa).

20. V.H. Anwar, I.J. Zakaria, and S. Afrizal Jurnal Biologi Universitas Andalas, 3,1: 20-26 (2014). (in Bahasa).

21. Insafitri. Jurnal Kelautan, 3,2: 112-116 (2010). (in Bahasa).

22. A. Romadhon, F. Yulianda, D.G. Bengen, and L. Adrianto, Tata Loka, 15,3: 218-234. DOI: 10.14710/tataloka.15.3.218-234 (2013). (in Bahasa).

23. B. Riegl, A. Bruckner, L. Steve, Coles, P. Renaud, and R.E. Dodgea, The Year in Ecology and Conservation Biology: Ann. N.Y. Acad. Sci. 
1162 : 136-186. DOI : 10.1111/j.174 96632.2009.04493.x (2009).

24. L.S. Hoek, and E.K . Bayoumi,. IOSR Journal of Pharmacy and Biological Sciences (IOSR-JPBS), 12,II: 59-63. DOI: 10.9790/3008-1202025963 (2017).

25. E.F. Ardiansyah, Hartoni, and L. Litasari, Maspari Journal, 5,2: 111-118 (2013). (in Bahasa).

26. Z. Hidayah, National Seminar of Marine VIII, B3 : 88-96 (2012). (in Bahasa).
27. K. Kleemann, Tropical Marine Biology II : Classification of Scleractinian (Stony) Corals. (University of Vienna, Vienna, 2002).

28. McClanahan, T.R. In Coral Reef Conservation. I.M. Cote et al., Eds.: 147-182. (Cambridge University Press. Cambridge, UK, 2006).

29. A. Muqsit, P. Dewi, and T. Zamdial, Jurnal Enggano, 1,1: 75-87 (2016). (in Bahasa).

30. M.R. Syahrir, A. Jayadi, Adnan, Yasser M., and Hanjoko, T. Internationl Journal of Science and Engineering, 8,1: 60-64. DOI: https://doi.org/ 10.12777/ijse.8.1.60-64 (2015). 